\title{
Mass cultivation of new algae Tetraselmis straiata BBRR1 under open raceway ponds for biodiesel and biocrude production
}

Annakkili Baskara Boopathy ${ }^{1,2,3}$, Thanasekaran Jayakumar ${ }^{3}$, Muthu Ganasan Rajaram ${ }^{1}$, Natarajan Mohan ${ }^{1}$, Chinnasamy Senthil ${ }^{4}$, Subramanian Nagaraj ${ }^{1}$, Ramasamy Rengasamy ${ }^{1}$, Manjunath Manubolu ${ }^{5}$, Joen-Rong Sheu ${ }^{3 *}$, Chao-Chien Chang $g^{6,7,8^{*}}$

${ }^{1}$ Centre for Advanced Studies in Botany, University of Madras, Guindy Campus, Chennai-600 025, Tamil Nadu, India; E-Mail: annakkilibaskar@gmail.com (A.-B.B); raja.ram091@gmail.com (M.-G.R); jnmohan08@gmail.com (N.M); nagalilly@gmail.com (S.N); profrrengasamy@yahoo.com (R.R)

${ }^{2}$ Department of Biochemistry, Caussanel College of Arts and Science, Muthupettai, Ramanathapuram-623523,Tamil Nadu, India

${ }^{3}$ Department of Pharmacology, Graduate Institute of Medical Sciences, Taipei Medical University, Taipei, Taiwan; tjaya_2002@yahoo.co.in (T.J);

${ }^{4}$ Aban Biotechnology division, Thandalam - 602 105, Kanchipuram, Tamil Nadu, India; EMail: senthilc@aban.com (C.S); ${ }^{5}$ Department of Evolution, Ecology and Organismal Biology, Ohio State University, Ohio-43212, USA; E-Mail: manubolu.1@osu.edu (M.M)

${ }^{6}$ Department of Cardiovascular Center, Cathay General Hospital, 106 Taipei, Taiwan; ${ }^{7}$ Department of Pharmacology, School of Medicine, College of Medicine, Taipei Medical University, 106 Taipei, Taiwan; ${ }^{8}$ Division of Cardiology, Department of Internal Medicine, School of Medicine, College of Medicine, Fu Jen Catholic University, 242 New Taipei City, Taiwan

*Correspondence to: Dr. Joen-Rong Sheu, Graduate Institute of Medical Sciences, College of Medicine, Taipei Medical University, No. 250, Wu-Hsing St., Taipei 11031, Taiwan. Tel: +8862-27361661 ext. 3199; Fax: +886-2-27390450; E-mail: sheujr@tmu.edu.tw; Dr. Chao-Chien Chang, Department of Cardiology, Cathay General Hospital, No. 280, Sec. 4, Jen-Ai Rd, Taipei 106, Taiwan. Tel: +886-2-27082121-3116; Fax:+886-2-27099408; e-mail: change@,seed.net.tw 


\begin{abstract}
In the process of modernization and development, a human being always needed energy, which increased the dependency on the available sources of fossil fuel. Tetraselmis, a green algal genus belong to the order Chlorodendrales, are described by their strong green coloured chloroplast, flagellated cell bodies, and the occurrence of a pyrenoid within the chloroplast. In this study, four different strains of Tetraselmis species were successfully isolated from the saltpans Kovelong, Chennai, Tamil Nadu, India. The isolated strains were cultured in the normal basal medium and their morphological features were subsequently studied. The species of Tetraselmis straiata (T. straiata) Butcher BBRR1 was confirmed using molecular identification of $18 \mathrm{~S}$ rRNA gene analysis and its observed systematic position. Among the four different isolates, T. straiata Butcher BBRR1 recorded a highest biomass concentration of $0.58 \pm 0.021$ $\mathrm{g} \mathrm{L}^{-1}, 15 \%$ lipids, $19 \%$ proteins and $17 \%$ carbohydrates when it grown under laboratory condition. Whereas, in open raceway ponds, T. straiata BBRR1 produced $0.95 \pm 0.06 \mathrm{~g} \mathrm{~L}^{-1}$ biomass, $19 \%$ lipids, $28 \%$ proteins and $21 \%$ carbohydrates in an modified CFTRI I medium. The fatty acids profile of $T$. straiata Butcher BBRR1 showed the presence of 33.14 \% Palmitic acid, 22.64\% 11- Octadecenoic acid and $21.94 \%$ Heptadecanoic acid. Since T. straiata BBRR1 can be cultivated in open ponds without a major contaminations, this species can be used as novel biomass feedstock to produce biofuels. This study may suggest the potential of $T$. straiata BBRR1 for biofuel production and could compete the energy demand in the future. In addition, this species contains healthful components of carotenoids, lipids and proteins, all these may provide a health benefits beyond basic nutrition.
\end{abstract}

Keywords: green algae; biomass; fatty acids; Tetraselmis straiata; lipids; carotenoids; raceway ponds 


\section{Introduction}

In the process of modernization and development, human being always needed energy, which increased the dependency on the available fossil fuel sources. The exhaustive use of fossil fuel sources has raised the serious concerns worldwide not only about energy security but also for negative impact on environment. India's growing demand for petroleum-based fuel has created challenges for the country's energy security, as almost $90 \%$ of its crude oil requirement is imported from oil producing countries. Algae have been widely used for fuel production because of their high photosynthetic efficiency, high biomass production, and fast growth [1]. Microalgae as biomass has potential chemical composition such as proteins, lipids and carbohydrates [2]. Many algae accumulate substantial amounts of non-polar lipids, mostly in the form of tri acyl glycerol or hydrocarbons, and these levels may reach up to $20-50 \%$ of dry cell weight. Algae can also grow in saline, brackish and coastal seawater with slight struggle [3]. Microalgae can provide an alternative biofuel feedstock due to their rapid growth rate, greenhouse gas fixation ability (net zero emission balance) and high production capacity of lipids and do not compete with human and animal food crops. Moreover, they will grow on non-arable land and saline water [4].

Microalgae cultivation is a promising methodology for solving some of the future problems of biomass production (i.e. renewable food, feed and bioenergy production). There is no doubt that in conjunction with conventional growth systems, novel technologies must be developed in order to produce the large-scale sustainable microalgae products [5]. The most conservative scenario contains algae oil from microalgae grown in open ponds on non-arable land filled with salt water [6]. Many algae are exceedingly rich in oil, which can be converted into biodiesel. The oil content of some microalgae exceeds $80 \%$ of the dry weight of algae 
biomass [7]. Aquatic biomasses present an easy adaptability to grow in different conditions either in fresh or marine water or in a wide range of $\mathrm{pH}$. This makes the aquatic biomass more adaptive or an enhanced $\mathrm{CO}_{2}$ fixation to afford a high biomass production. $\mathrm{CO}_{2}$ is usually bubbled from beneath at rates for optimum uptake by microalgae cells [8]. Microalgae are traditionally considered as good source of fatty acids [3], and the fatty acids in microalgae are suitable for biofuel synthesis [9]. The fatty acid profiles of microalgae has been well established $[10,11]$. Microalgae have a strong capacity to produce lipids, which can be easily converted to biodiesel.

The most cost effective cultivation system for mass culture production of Tetraselmis straiata (T. straiata) BBRR1 is to grow in an outdoor open airway pond. However, trials on cultivating T. straiata in non-axenic systems often fail due to thriving of other green algal and cyanobacterial contaminants, and hence it relatively slow downs the growth of $T$. straiata. Therefore, methodological or technological breakthrough to control the growth of these contaminating species is awaited to minimize the oil production cost using microalgae. The aim of the present study is to mass cultivate the alga $T$. straiata isolated from the saltpans bodies Kovelong, Chennai, Tamil Nadu, India in the open raceway pond. The growth performance in terms of biomass, pigments, lipids, proteins and carbohydrates were analyzed. Carotenoids are linked with numerous health benefits, such as hindrance of age-related macular degeneration, cataract, some cancers, rheumatoid arthritis, muscular dystrophy and cardiovascular problems. Since T. straiata holds substantial amounts of carotenoids, this species may also have health benefits for human beings.

\section{Results and Discussion}

\subsection{Isolation of Tetraselmis spp.}


In the present attempt, water samples collected from the saltpans (60 ppt) Kovelong, Chennai, Tamil Nadu, India, were brought to the laboratory and segregated by using spread plate technique (Figure 1a,b.) on $\mathrm{f} / 2$ agar medium. Four different isolates of quardriflagellate alga, Tetraselmis were isolated and identified as, Tetraselmis chuii, T. gracilis, T. straiata and T. tetrathele based on their morphological features of colour, colony, morphology and cell size [12]. Tetraselmis is a euryhaline microalga and commonly present in saltpans and marine environments $[13,14]$. The colonies $T$. chuii Butcher is a green four-flagellated alga, ovoid body shape with a distinct curve (cell length: 12-14 $\mu \mathrm{m}$, width: 9-10 $\mu \mathrm{m}$ ). T. gracilis (Kylin) Butcher cells are ellipsoid and slightly compressed, with four anterior lobes; pyrenoid large, subbasal, with U-shaped starch shield; median eyespot, large, red - orange. Its cell length: 8-12 $\mu \mathrm{m}$ and width 6-9 $\mu \mathrm{m}$. T. striata Butcher cells showed marked longitudinal rows of granules and posterior eyespot with cell length of 10-21 $\mu \mathrm{m}$ and width 8-17 $\mu \mathrm{m}$. T. tetrahele (G.S.West) Bucher cells compressed, with deep and wide four-lobed apical furrow and its cell length 10-16 $\mu \mathrm{m}$ and width $8-12 \mu \mathrm{m}$. These colonies are bright green and grown in $\mathrm{f} / 2$ medium under $30 \mu \mathrm{Em}^{-2} \mathrm{~S}^{-1}$ light intensity $12 / 12$ light dark cycle at $24 \pm 1^{\circ} \mathrm{C}$. For marine and brackish strains, the $\mathrm{f} / 2$ medium is the most commonly used medium [15].

\subsection{Dry biomass and total lipids in Tetraselmis species}

The four different species of microalgae Tetraselmis were taken for the growth analysis under laboratory conditions revealed that the isolate of $T$. straiata showed a maximum biomass and lipid content of $0.58 \pm 0.021 \mathrm{~g} \mathrm{~L}^{-1}$ (Table 1) and $151 \pm 3 \mathrm{mg} \mathrm{L}^{-1}$ (Table 2), respectively, and followed by T. chuii, T. tetrahele and T. gracilis (Figure 2a, b). Huerlimann et al. [16] observed that $T$. gracilis showed a maximum biomass of $0.35 \mathrm{~g} \mathrm{~L}^{-1}$, which was $8.0 \%$ less than the test 
alga, T. straiata and the specific growth rate of 0.25 . Arkronrat et al. [17] reported a maximum and a specific growth rate of 0.16 in Tetraselmis sp., which was $36 \%$ less than the present alga, T. straiata. In the present study, the isolate of $T$. straiata Butcher had maximum lipid content than the other three isolates. Thirty-day-old culture of T. straiata Butcher was harvested and analysed the biochemical parameters. T. straiata had maximum lipid content of $33.60 \%$ dry weight and lipid productivity of $29.14 \mathrm{mg} \mathrm{L}^{-1}$ day $^{-1}$ (Table 3). Huerlimann et al. [16] had found only $18.6 \mathrm{mg} \mathrm{L}^{-1}$ day $^{-1}$ of lipid productivity on Tetraselmis sp., which was $37 \%$ less than the present isolate $T$. straiata.

The morphology of alga within in each chemical competition could vary in relation to age and culture conditions [18]. As the morphological heterogeneity of the alga makes the identification difficult, molecular tools like PCR play a vital role in confirming the systematic position of the experimental alga. In the present study, a partial $18 \mathrm{~S}$ region of the ribosomal RNA gene was isolated and amplified with the specific primers. The sequence was found $99 \%$ similarity with $T$. straiata JQ315813 KMMCC 1157 strain. The obtained sequence was compared with the existing sequences in the NCBI database by the BLAST algorithm homology (sequence identity) confirmed with a close relationship of the isolated candidate $T$. straiata. Based on the classical taxonomy as well as molecular taxonomy, the test alga was identified and confirmed as T. straiata Butcher BBRR1 (Figure 3). The sequence was submitted in the GenBank, NCBI and the Accession Number is KP317837.

\subsection{Phytochemicals, lipids, biomass and fatty acids of T. straiata BBRR1}

The isolate T. straiata BBRR1 performed well than the rest of three isolates in the laboratory conditions and was scaled up to $150 \mathrm{~L}$ in an open pond. It was then transferred to the raceway pond containing $1350 \mathrm{~L}$ Modified CFTRI - ABRR I medium. The initial concentrations 
of $0.05 \pm 0.004 \mathrm{mg} \mathrm{L}^{-1}$ and $0.03 \pm 0.002 \mathrm{mg} \mathrm{L}^{-1}$ of chlorophyll $a$ and $\mathrm{b}$ were increased during the growth period and they raised up to $6.13 \pm 0.005 \mathrm{mg} \mathrm{L}^{-1}$ and $5.23 \pm 0.003 \mathrm{mg} \mathrm{L}^{-1}$ on $15^{\text {th }}$ and $18^{\text {th }}$ day, respectively. The concentration of chlorophyll $a$ and $\mathrm{b}$ were recorded maximum on $15^{\text {th }}$ day and reached a plateau thereafter (Figure $4 \mathrm{a}, \mathrm{b}$ ), although the productivity in terms of biomass continued to increase until day 15 . This data indicated that the cells continued to grow resulting on the net increase in the biomass concentration up to day 15. Similarly, the initial concentration of $0.15 \pm 0.002 \mathrm{mg} \mathrm{L}^{-1}$ of total carotenoid content was increased up to $56.5 \pm 0.23 \mathrm{mg} \mathrm{L}^{-1}$ on $18^{\text {th }}$ day (Figure 4c). The initial biomass of $0.12 \pm 0.01 \mathrm{~g} \mathrm{~L}^{-1}$ was increased up to a maximum of 0.95 $\pm 0.06 \mathrm{~g} \mathrm{~L}^{-1}$ on Modified CFTRI-ABRR I medium, which was $28 \%$ higher than control on $15^{\text {th }}$ day (Figure 5). Based on the total biomass productivity, the lipid production and comparative biochemical analysis was calculated in T. straiata BBRR1 cultivated under laboratory and open raceway pond as shown in Tables 3 and 4 . Daily biomass productivity for the $T$. straiata BBRR1 cultivated under open raceway pond was observed about 0.063 , and $0.050 \mathrm{~g} \mathrm{~L}^{-1} \mathrm{~d}^{-1}$, specific growth rates of 0.45 and 0.39 , division rates of 0.64 and 0.56 and generation times of 1.55 and 1.79 in the Modified CFTRI-ABRR I medium and f medium (control), respectively (Table 5). The present isolate, T. straiata BBRR1 showed an aerial biomass productivity of 8.83 $\mathrm{g} \mathrm{L}^{-1} \mathrm{~m}^{2} \mathrm{~d}^{-1}$ in Modified CFTRI-ABRR I medium. Similarly, Fon-Sing and Borowitzka [19] reported that the alga recorded average biomass productivity of $8.3 \mathrm{~g} \mathrm{~L}^{-1} \mathrm{~m}^{2} \mathrm{~d}^{-1}$ in Tetraselmis sp.

The alga had a maximum total lipid of $152 \pm 39 \mathrm{mg} \mathrm{L}^{-1}$ on $18^{\text {th }}$ day, which was $19 \%$ more than control (f medium). Total lipid percentage / ash - free biomass of the sample in Modified CFTRI-ABRR I medium was $27.50 \%$, as against $29.76 \%$ in control on $18^{\text {th }}$ day. The organism showed lipid productivity of 8.43 and $7.06 \mathrm{mg} \mathrm{L}^{-1} \mathrm{~d}^{-1}$ when it was grown in Modified CFTRI ABRR I medium and control medium, respectively. Tetraselmis was the most suited for the mass 
cultivation due to fast growth, ease of culture and relatively high lipid content. Rodolfi et al. [11] reported Tetreselmis and Nannochloropsis showed high lipid productivity and found to be the promising marine species for biomass production.

Nutrients management could change biochemical constituents of algae reported by Hsieh and $\mathrm{Wu}[20]$. During the study period, the lipid content in T. straiata BBRR1 increased due to growth limiting factors like nutrient deficiency in the lack of nitrogen and phosphate sources. Pernet et al. [21], Li et al. [22] and Arumugam et al. [23] also reported that the biomass and lipid content of microalgae were affected at different cultivation and nutrients conditions. The culture in the open system was observed periodically under compound microscope, and the end of the study the algal biomass in the pond was harvested and dried. The different parameters such as lipids, proteins, and carbohydrates were similar to the observations made under laboratory conditions and open raceway ponds (Table 4).

The alga T. straiata BBRR1 produced $15.2 \%$ of lipid content on its dry weight basis under open raceway pond. The total content of lipids varies from $1-85 \%$ of the dry weight with values higher than $40 \%$ being typically reached under nutrient limitation studied by Regan [24]. The fatty acid composition of hexane extracted FAMEs was analysed by GC-MS. The isolate $T$. straiata BBRR1 revealed the presence of $33.14 \%$ of Palmitic acid, methyl ester, followed by 22.64\% 11- Octadecenoic acid, methyl ester, 21.94\% Heptadecanoic acid, 16 -methyl ester and minimum of 5.94\% Palmitoleic acid, methyl ester, and 3.14\% Pentadecanoic acid, methyl ester (Table 6). Similarly, Sharmin et al. [9] found significant amounts of myristic acid (C 14:0), palmitic acid (C 16:0), stearic acid (C 18:0), and palmitoleic acid (C 16:1) in marine microalgae Skeletonema costatum available in Bangladesh Coast and they suggested this algae to be used as biodiesel feedstock. Moreover, T. straiata BBRR1 contains hexadecatrienoic acid, 
benzenedicarboxylic acid, oleic acid, arachidonic acid, eicosapentaenoic acid and 9Octadecenoic acid methyl ester.

Based on the results obtained in the present study, the volumetric productivity of biomass were $0.089 \mathrm{~g} \mathrm{~L}^{-1} \mathrm{~d}^{-1}$ in Modified CFTRI-ABRR I medium. This study also indicates that $T$. straiata BBRR1 has the potential to produce 48.72 dry tons of biomass ha ${ }^{-1}$ year $^{-1}$. In the view of shrinking fossil fuel sources, algae mass cultivation for biofuel production is gaining importance day by day. However, the cost of production of algal biomass needs to be reduced below \$200 dry tons to make algae as an attractive biomass feedstock for biofuel production. However, the cost of growth medium used for mass cultivation of T. straiata BBRR1 was estimated as $\$ 53,000$. Similarly, the cost of the cultivation media required to produce 1 ton of algal biomass through open raceway ponds was estimated as $\$ 1128 \mathrm{t}^{-1}$. As the estimated cost of growth medium used for mass cultivation of $T$. straiata BBRR1 was higher than the selling cost of biofuel algae, future research efforts are needed to reduce the nutrients cost through the use of municipal, agricultural and industrial waste streams rich in organic and inorganic nutrients which are renewable in nature.

\section{Materials and Methods}

\subsection{Isolation of Tetraselmis spp.}

The algal samples collected from the saltpans of Kovelong, Chennai, Tamil Nadu, India were brought to the laboratory and the colonies were segregated based on their morphological features using compound microscope [12]. A single colony of the four different isolates was picked up with the help of micropipette. After thoroughly washed with sterile f/2 medium for five times, the isolates was subjected to grow in the $\mathrm{f} / 2$ agar medium [15]. The culture medium 
was kept at $24 \pm 1^{\circ} \mathrm{C}$ in thermostatically controlled room, illuminated with cool fluorescent lamps at irradiance of $30 \mu \mathrm{Em}^{-2} \mathrm{~s}^{-1}$, under 12/12 light dark cycle.

\subsection{Laboratory studies}

Experiments were conducted in $500 \mathrm{~mL}$ Erlenmeyer flasks with $270 \mathrm{~mL}$ of sterile $\mathrm{f} / 2$ medium and inoculated with $30 \mathrm{~mL}$ of optimally grown four different isolates of $T$. straiata separately. The experimental studies were carried out for a period of 21 days. The growth parameters such as cell number, biomass [25], the levels of different pigments such as Chlorophyll $a$, Chlorophyll $\mathrm{b}$ and carotenoids [26], total carbohydrates [27], proteins [28] and lipids [29] were recorded at every 3 days interval during the study period. It revealed that $T$. straiata Butcher showed good growth and lipid productivity than the rest. Therefore, this alga was chosen for further investigation.

\subsection{Molecular characterization}

The genomic DNA samples of T. straiata were isolated from the lyophilized algal biomass using the PCR kit obtained from GENEI, Bangalore, India. RNA contamination was eliminated by digesting the extract with $10 \mu \mathrm{g}$ of RNase-A for $30 \mathrm{~min}$ at $37^{\circ} \mathrm{C}$. The amount of DNA of the sample was quantified by measuring its absorbance at $260 \mathrm{~nm}$ in a spectrophotometer. The optical density (OD) of 1.0 corresponds to $50 \mu \mathrm{g} / \mathrm{mL}$ of double stranded DNA [30] and the purity of DNA was determined at 260 and $280 \mathrm{~nm}$. DNA solution that had a value of 1.8 obtained from the data recorded at $260 \mathrm{~nm} / 280 \mathrm{~nm}$ was considered as pure.

In the present study, the $18 \mathrm{~S}$ rRNA gene region of the $T$. straiata isolates were subjected for the amplification of the primers (GENEI, Bangalore, India) as described by Richards et al. [31]. The forward primer 5'- GTAACCCGTTGAACCCCATT - 3' and reverse primer 5'- 
CCATCCAATCGGTAGTAGCG - 3' were used as described by Liu et al. [32]. Polymerase chain reaction $(\mathrm{PCR})$ was performed in a $\mathrm{ABI}$ thermal cycler $(\mathrm{ABI})$ using a $\mathrm{PCR}$ program with initial denaturing at $95^{\circ} \mathrm{C}$ for $5 \mathrm{~min}$, followed by 35 cycles of denaturation at $95^{\circ} \mathrm{C}$ for $1 \mathrm{~min}$, annealing at $58^{\circ} \mathrm{C}$ for 55 seconds and extension at $72^{\circ} \mathrm{C}$ for 50 seconds and a final extension at $72^{\circ} \mathrm{C}$ for 10 min. The PCR products were separated through agarose gel electrophoresis. The purified PCR products were separated using $1.4 \%$ agarose gels and stained with $0.5 \mu \mathrm{g} / \mathrm{mL}$ ethidium bromide and the gel was viewed and captured using Vilber Loumart Gel Documentation system. Sequences were determined by the chain termination method with the use of Dye Deoxy Terminator Cycle Sequencing Kit (Perkin Elmer Applied Bio - system, UK) using an AV1377 automated DNA sequencer.

\subsection{Familiarization of T. straiata Butcher BBRR1 for outdoor condition}

The isolate of T. straiata BBRR1 grown under laboratory condition produced high biomass yield and lipid content was scaled up to 1 and $2 \mathrm{~L}$ in flasks for 2 weeks and further scaled up to $10 \mathrm{~L}$ in transparent carboys for 2 weeks. The $15 \mathrm{~L}$ culture grown under laboratory condition was used as seed material, inoculated in $135 \mathrm{~L}$ medium in a $1.0 \mathrm{~m}^{2}$ of $150 \mathrm{~L}$ capacity mini open raceway pond (Length $2.2 \mathrm{~m}$; Width $0.50 \mathrm{~m}$; Depth $0.26 \mathrm{~m}$ ) floors are coated with FRP (FibreReinforced Polymer) material and incubated for 2 weeks. The raceway ponds are provided with paddle wheel system for the aeration at $10 \mathrm{rpm}$. The culture was mixed with paddle wheel system during daytime. The alga in the pond was subjected for adaptation to open air condition for 2 cycles (sub-culturing at an intervals of 2 weeks). During the experimental period the evaporation of water was compensated with chlorine treated bore well water. The raceway ponds were protected from dust on the top with transparent polythene sheet. 


\subsection{Mass culture of T. straiata BBRR1 in open raceway pond}

This experiment was conducted in a concrete raceway pond $10.0 \mathrm{~m}^{2}$ of $1500 \mathrm{~L}$ capacity (Length $7 \mathrm{~m}$; Width $1.5 \mathrm{~m}$; Depth $0.26 \mathrm{~m}$ ) floors are coated with reinforced polymer. The inoculum was raised in the following order: Optimally grown $15 \mathrm{~L}$ of $T$. straiata BBRR1 culture obtained from the laboratory condition was inoculated into $1.0 \mathrm{~m}^{2}$ raceway pond with a biomass concentration of $0.06 \mathrm{~g} \mathrm{~L}^{-1}$ contained $135 \mathrm{~L}$ medium and kept for 10 days. Then the culture (150 L) was inoculated to $10.0 \mathrm{~m}^{2}$ raceway pond contained $1350 \mathrm{~L}$ of basal $(\mathrm{f} / 2)$ medium and the culture height in the pond was maintained at $15 \mathrm{~cm}$ level. The algal culture was mixed with paddle wheel system during day time to prevent settling and enhance dissolved $\mathrm{CO}_{2}$ concentration. This experiment was conducted for a period of 21 days in batch mode. At every 3 days interval, $\mathrm{pH}$, biomass, pigments, total carbohydrates, proteins and lipids were analyzed and recorded. Microscopic analysis was carried out daily to check the purity of the culture. The average temperature and light intensity were ranged from $28^{\circ} \mathrm{C}$ to $35^{\circ} \mathrm{C}$ and 42000 and 52000 lux, respectively. At the end of the study period, the algal biomass was harvested and analyzed for different parameters.

\subsection{Biomass harvest of T. straiata BBRRI}

In open raceway ponds, the biomass of $T$. straiata BBRR1 was harvested by switch off the paddle wheel for a period of $24 \mathrm{~h}$. The biomass was collected after the medium was drained off. The algal cells settled at the bottom in the open raceway pond was harvested after $12 \mathrm{~h}$ through autoflocculation on 21 day. The biomass in the open raceway pond was washed with ground water and the cells were allowed to settle. This process was repeated for 3 times in order to 
remove the excess salt in the algal biomass. The washed algal cells were spread on white plastic sheet and dried over the sun light for $3 \mathrm{~h}$ followed by oven drying at $60^{\circ} \mathrm{C}$ for $8 \mathrm{~h}$.

\subsection{Biomass estimation}

Twenty five millilitres of algal culture was taken and washed thrice with $25 \mathrm{~mL}$ of isotonic solution containing 0.65 $\mathrm{M}$ ammonium formate [25] in order to remove excess salt. Pre weighed Whatman GF/C glass microfiber filters $(1.2 \mu \mathrm{m})$ was used to obtain the biomass after filtration in the moisture analyser (Mettler Toledo HR83). Then, the filter along with the biomass was placed in the moisture analyzer and its final dry weight was recorded after drying at $100^{\circ} \mathrm{C}$ for $\sim 8$ minutes. Dry weight was calculated after subtracting the filter weight and expressed the values as $g^{-1}$.

\subsection{Extraction of algal oil and fatty acid analysis}

Ten grams of dried algal biomass was treated with hexane 1:5 (w/v) and extracted algal oil by using Soxhlet apparatus at the boiling temperature of the solvent for $8 \mathrm{~h}$. The solvents containing the algal oil were filtered through Whatman GF/C filter paper. The solvents were recovered using rotary evaporator at the respective boiling temperature. The algal oil was recorded gravimetrically and expressed the values as ash-free biomass.

\subsection{Acid transesterification}

Ten gram of total lipid was extracted from the alga by using chloroform and methanol $(2: 1)$ and $0.6 \mathrm{~mL} \mathrm{~g}^{-1}$ of sulphuric acid. The reaction mixture was kept at $90^{\circ} \mathrm{C}$ in a water bath for $40 \mathrm{~min}$ and intermittently mixed. Then, it was allowed to cool at room temperature, and added $2.0 \mathrm{~mL} \mathrm{~g}^{-1}$ of distilled water and mixed for $45 \mathrm{sec}$. After phase separation the solvent layer 
contained biodiesel of fatty acid methyl ester (FAME) was collected and transferred to a pre weighed glass vial. The solvent was evaporated using liquid $\mathrm{N}_{2}$, and quantified the amount of biodiesel gravimetrically. The fatty acid composition of the sample was analysed by GC-MS. FAME was analyzes by GC-MS (Agilent 6890 gas chromatograph, 15 m Alltech EC - 5 column (250 $\mu$ I.D., $0.25 \mu$ film thickness). A JEOL GCmate II bench top double-focusing magnetic sector mass spectrometer operating in electron ionization (EI) mode with TSS-2000 ${ }^{1}$ software was used for all the analyses. Identification of FAME was made by matching their recorded spectra with the data bank mass spectra of NIST library V 11 provided by the instruments software.

\subsection{Statistical analysis}

Throughout the study period, triplicates were maintained for each experiment. The results were expressed as Mean \pm standard deviations. Data were analysed statistically using Origin Pro.v 8.0 for Windows.

\section{Conclusion}

This study envisaged on researching the feasibility and sustainability of microalgae as biofuel feedstock to meet the energy crisis. In the present attempt, four different species of Tetraselmis belong to Chlorophytes were isolated as T. chuii Butcher, T. gracilis (Kylin) Butcher, T.straiata Butcher and T. tetrathele (G.S.West) Bucher. Among these isolates, T. straiata contained a maximum biomass productivity in indoor and outdoor conditions. This is the first attempt to cultivate $T$. straiata BBRR1 in an open outdoor raceway pond for biomass and biofuel applications. As this isolate can be grown in open ponds without any major 
contaminations, it can be used as a novel biomass feedstock to produce various biofuels. This work revealed the potential of $T$. straiata BBRR1 for biofuel production and could match the demand of energy in future.

\section{Acknowledgements}

The authors A.B.B and M.G.R are thankful to Aban Biotechnology Division Pvt., Ltd., Thandalam, Tamil Nadu, India for the open raceway ponds and for the partial financial support. The authors T.J. and J.R.S acknowledge the Ministry of Science and Technology of Taiwan (MOST 104-2622-B-038-003, MOST 104-2320-B-038-045-MY2, MOST 106-2320-B-038-012; MOST 107-2320-B-038-035-MY2).

\section{Authors Contributions}

A.B.B., M.G.R. and R.R conceived the project and designed the experiments. N.M., C.S. and S.N assisted to wrote the paper. T.J., M.M. and R.R wrote the paper. J.R.S. and C.C.C contributed clarifications and guidance on the manuscript. All authors were involved in editing the manuscript.

\section{Conflicts of Interest}

The authors declare no conflict of interest. 


\section{References}

1. Miao, X.; Wu, Q. High yield bio-oil production from fast pyrolysis by metabolic controlling of Chlorella protothecoides. J. Biotechnol. 2004, 110, 85-93.

2. Raja, A.; Vipin, C.; Aiyappan, A. Biological importance of marine algae an overview. Int. J. Curr. Microbiol. App. Sci. 2013, 2, 222-227.

3. Borowitzka, M.A. High-value products from microalgae - their development and commercialisation. J. Appl. Phycol. 2013, 25, 743-756.

4. Nigam, P.S.; Singh, A. Production of liquid biofuels from renewable resources. Prog. Energy Combust. Sci. 2011, 37, 52-68.

5. Moheimani, N.R.; Mark, P.; McHenry, K.; de Boer, K.; Parisa, B. Biomass and Biofuels from Microalgae: Advances in Engineering and Biology. Cham, Springer, 2015.

6. Florentinus, A.; Hamelinck, C.; Lint, S.D.; Iersel, S.V. Worldwide Potential of Aquatic Biomass. Utrecht, Ecofys. 2008.

7. Chisti, Y. Biodiesel from microalgae. Biotechnol adv. 2007, 25, 294-306.

8. Earthrise. About earthrise: Our farm - Earthrise nutritionals. Retrieved from http://www.earthrise.com/farm.html. 2009.

9. Sharmin, T.; Hasan, M.; Md, C.; Aftabuddin, S.; Rahman, M.A.; Khan, M. Growth, Fatty Acid, and Lipid Composition of Marine Microalgae Skeletonema costatum Available in Bangladesh Coast: Consideration as Biodiesel Feedstock. J. Mar. Biol. 2016, 8, 33-51.

10. Griffiths, M.J.; Harrison, S.T. Lipid productivity as a key characteristic for choosing algal species for biodiesel production. J. Appl. Phycol. 2009, 21, 493-507. 
11. Rodolfi, L.; Chini Zittelli, G.; Bassi, N.; Padovani, G.; Biondi, N.; Bonini, G.; Tredici, M.R. Microalgae for oil: strain selection, induction of lipid synthesis and outdoor mass cultivation in a low-cost photobioreactor. Biotechnol. Bioeng. 2009, 102, 100-112.

12. Iyengar, M.O.P.; Desikachary, T.V. Volvocales. Indian Council of Agricultural Research. 1981.

13. Kawabata, Y.;Nakahara, H.; Katayama, Y.; Ishida, N. The phytoplankton of some saline lakes in Central Asia. Int. J. of Salt Lake Res. 1997, 6, 5-16.

14. López-González, P.J.; Guerrero, F.; Carmen C.M. Seasonal fluctuations in the plankton community in a hypersaline temporary lake (Honda, southern Spain). Inter. J. Salt Lake Res. 1998, 6, 353-371.

15. Guillard, R.R.L.; Ryther, J.H. Studies of marine planktonic diatoms. I. Cyclotella nana Hustedt and Detonula confervacea Cleve. Can. J. Microbiol. 1962, 8, 229-239.

16. Huerlimann, R.; De Nys, R.; Heimann, K. Growth, lipid content, productivity, and fatty acid composition of tropical microalgae for scale-up production. Biotech. Bioeng. 2010, $107,245-257$.

17. Arkronrat, W.; Deemark, P.; Oniam, V. Growth performance and proximate composition of mixed cultures of marine microalgae (Nannochloropsis sp. and Tetraselmis sp.) with monocultures. Songklanakarin. J. Sci. Tech. 2016, 38, 326-345.

18. Metzger, P.; Largeau, C. Botryococcus braunii: a rich source for hydrocarbons and related ether lipids. Appl. Microbiol. Biotechnol. 2005, 66, 486-496.

19. Fon-Sing, S.; Borowitzka, M.A. Isolation and screening of euryhaline Tetraselmis spp. Suitable for large-scale outdoor culture in hypersaline media for biofuels. J. Appl. Phycol. 2015, 28, 1-14. 
20. Hsieh, C.H.; Wu, W.T. Cultivation of microalgae for oil production with a cultivation strategy of urea limitation. Biores. Technol. 2009, 100, 3921-3926.

21. Pernet, F.; Tremblay, R.; Demers, E.; Roussy, M. Variation of lipid class and fatty acid composition of Chaetoceros muelleri and Isochrysis sp. grown in a semicontinuous system. Aquaculture. 2003, 221, 393-406.

22. Li, Q.; Du, W.; Liu, D. Perspectives of microbial oils for biodiesel production. Appl. Microbial. Biotechnol. 2008, 80, 749-756.

23. Arumugam, M.; Agarwal, A.; Arya, M.C.; Zakwan, A. Influence of nitrogen sources on biomass productivity of microalgae Scenedesmus bijugatus. Biores. Technol. 2013, 131, 246-249.

24. Regan, D.L. Other micro-algae. In: Borowitzka, M.A. and Borowitzka, L.J. (eds.) Microalgal biotechnology. Cambridge, Cambridge University Press, 1988, 135-150.

25. Moheimani, N.R. The culture of Coccolithophore algae for carbon dioxide bioremediation. Ph.D. Thesis, Murdoch University. 2005.

26. Lichtenthaler H.K. Chlorophylls and carotenoids: pigments of photosynthetic membranes. Method Enzymol. 1987, 148, 350-382.

27. Dubois, M.; Gilles, K.A.; Hamilton, J.K.; Rebers P.A.; Smith, F. Colorimetric method for determination of sugars and related substances. Anal. Chem. 1956, 28, 350-356.

28. Lowry, O.H.; Rosebrough, N.S.; Farrand, A.L.; Randall, R.J. Protein measurement with folin phenol reagent. J. Biol. Chem. 1951, 193, 263-275.

29. Folch, J.; Lees, M.; Sloane S.G.H. A simple method for the isolation and purification of the total lipids from animal tissues. J. Biol. Chem. 1957, 226, 49-57. 
30. Sambrook, J.; Fritschi, E.F.; Maniatis, T. Molecular cloning: a laboratory manual, Cold Spring Harbor Laboratory Press, New York. 1989.

31. Richards, E.; Reichardt, M.; Rogers, S. Preparation of genomic DNA from plant tissue. Curr. Prot. Mol. Biol. 2002, 1, 2.3.3. J. Wiley and Sons, Inc.

32. Liu, K.H.; Yeh, Y.L.; Shen, W.C. Fast preparation of fungal DNA for PCR screening. J. Microbiol. Meth. 2011, 85,170-172. 


\section{Table captions}

Table 1. Biomass (dry wt.) content of T.tetrahele, T.gracilis, T.chuii and T.straiata grown in laboratory condition.

Table 2. Total lipid content of T.tetrahele, T.gracilis, T.chuii and T.straiata grown in laboratory condition.

Table 3. Biomass, lipid productivity and lipid percentage of different Tetraselmis spp.

Table 4. Comparative biochemical analysis of $T$. straiata BBRR1 grown under laboratory and open raceway pond.

Table 5. Daily productivity, specific growth rate, divisions per day and generation time of $T$. straiata BBRR1 cultivated under open raceway pond.

Table 6. Lipid profile of $T$. straiata BBRR1 grown under open raceway pond 


\section{Figure legends}

Figure 1. (a) Colonies of Tetraselmis spp. on $2 \%$ agar $\mathrm{f} / 2$ medium on $20^{\text {th }}$ day. (b) Tetraselmis tetrahele (A), Tetraselmis straiata (B), Tetraselmis chuii (C), Tetraselmis gracilis (D) on $18^{\text {th }}$ day culture.

Figure 2. (a) Dry Biomass and (b) total lipids of Tetraselmis spp. at different intervals.

Figure 3. PCR amplification of $18 \mathrm{~S}$ rRNA gene of $T$. straiata. Lane 1. DNA ladder (kB); Lane 2. PCR amplified product of T. straiata.

Figure 4. (a) Chlorophyll $a$ (b) Chlorophyll b and (c) total carotenoids of T. straiata BBRR1 in Modified CFTRI ABRR I medium at different intervals in $10.0 \mathrm{~m}^{2}$ open raceway pond.

Figure 5. Dry biomass of $T$. straiata BBRR1 in Modified CFTRI ABRR I medium at different intervals in $10.0 \mathrm{~m}^{2}$ open raceway pond 
Table 1

\begin{tabular}{ccccc}
\hline Days & $\begin{array}{c}\text { T.tetrahele } \\
\left(\mathrm{g} \mathrm{L}^{-1}\right)\end{array}$ & $\begin{array}{c}\text { T.gracilis } \\
\left(\mathrm{g} \mathrm{L}^{-1}\right)\end{array}$ & $\begin{array}{c}\text { T.chuii } \\
\left(\mathrm{g} \mathrm{L}^{-1}\right)\end{array}$ & $\begin{array}{c}\text { T.straiata } \\
\left(\mathrm{g} \mathrm{L}^{-1}\right)\end{array}$ \\
\hline $\mathbf{0}$ & $0.050 \pm 0.02$ & $0.060 \pm 0.03$ & $0.030 \pm 0.03$ & $0.030 \pm 0.02$ \\
$\mathbf{3}$ & $0.140 \pm 0.05$ & $0.170 \pm 0.06$ & $0.180 \pm 0.08$ & $0.200 \pm 0.04$ \\
$\mathbf{6}$ & $0.190 \pm 0.08$ & $0.200 \pm 0.011$ & $0.170 \pm 0.013$ & $0.240 \pm 0.05$ \\
$\mathbf{9}$ & $0.240 \pm 0.08$ & $0.280 \pm 0.015$ & $0.230 \pm 0.018$ & $0.300 \pm 0.06$ \\
$\mathbf{1 2}$ & $0.250 \pm 0.012$ & $0.310 \pm 0.021$ & $0.300 \pm 0.021$ & $0.350 \pm 0.011$ \\
$\mathbf{1 5}$ & $0.250 \pm 0.015$ & $0.350 \pm 0.025$ & $0.360 \pm 0.026$ & $0.380 \pm 0.013$ \\
$\mathbf{1 8}$ & $0.330 \pm 0.018$ & $0.330 \pm 0.032$ & $0.380 \pm 0.031$ & $0.420 \pm 0.017$ \\
$\mathbf{2 1}$ & $0.420 \pm 0.022$ & $0.310 \pm 0.035$ & $0.330 \pm 0.037$ & $0.580 \pm 0.021$ \\
$\mathbf{2 4}$ & $0.320 \pm 0.025$ & $0.160 \pm 0.037$ & $0.250 \pm 0.041$ & $0.310 \pm 0.026$ \\
\hline
\end{tabular}

Data represent mean \pm Standard Error (SE) of three replicates. 
Table 2

\begin{tabular}{ccccc}
\hline Days & $\begin{array}{c}\text { T.tetrahele } \\
\left(\mathrm{mg} \mathrm{L}^{-1}\right)\end{array}$ & $\begin{array}{c}\text { T.gracilis } \\
\left(\mathrm{mg} \mathrm{L}^{-1}\right)\end{array}$ & $\begin{array}{c}\text { T.chuii } \\
\left(\mathrm{mg} \mathrm{L}^{-1}\right)\end{array}$ & $\begin{array}{c}\text { T.straiata } \\
\left(\mathrm{mg} \mathrm{L}^{-1}\right)\end{array}$ \\
\hline $\mathbf{0}$ & $22 \pm 3$ & $21 \pm 4$ & $30 \pm 2$ & $44 \pm 2$ \\
$\mathbf{3}$ & $51 \pm 4$ & $44 \pm 4$ & $34 \pm 5$ & $52 \pm 4$ \\
$\mathbf{6}$ & $61 \pm 3$ & $51 \pm 3$ & $55 \pm 3$ & $61 \pm 5$ \\
$\mathbf{9}$ & $64 \pm 4$ & $59 \pm 2$ & $63 \pm 3$ & $72 \pm 4$ \\
$\mathbf{1 2}$ & $66 \pm 4$ & $66 \pm 4$ & $67 \pm 4$ & $77 \pm 3$ \\
$\mathbf{1 5}$ & $71 \pm 2$ & $83 \pm 5$ & $82 \pm 6$ & $103 \pm 2$ \\
$\mathbf{1 8}$ & $94 \pm 3$ & $92 \pm 3$ & $86 \pm 4$ & $120 \pm 3$ \\
$\mathbf{2 1}$ & $88 \pm 3$ & $80 \pm 2$ & $112 \pm 7$ & $151 \pm 3$ \\
$\mathbf{2 4}$ & $61 \pm 2$ & $68 \pm 3$ & $72 \pm 3$ & $80 \pm 2$ \\
\hline
\end{tabular}

Table 3

\begin{tabular}{llll}
\hline Tetraselmis spp. & $\begin{array}{l}\text { Biomass } \\
\text { productivity } \\
\left(\mathbf{g ~ L}^{-\mathbf{1}} \mathbf{d}^{-\mathbf{1}}\right)\end{array}$ & $\begin{array}{l}\text { Lipid productivity } \\
\left(\mathbf{~} \mathbf{~ L ~ L ~}^{-\mathbf{1}} \mathbf{d}^{-\mathbf{1}}\right)\end{array}$ & $\begin{array}{l}\text { \% Lipid content / } \\
\text { Dry biomass }\end{array}$ \\
\hline Tetraselmis chuii & $0.023 \pm 0.003$ & $5.33 \pm 0.005$ & $31.46 \pm 1.24$ \\
Tetraselmis gracilis & $0.024 \pm 0.004$ & $5.12 \pm 0.004$ & $27.88 \pm 1.12$ \\
Tetraselmis straiata & $0.025 \pm 0.004$ & $7.21 \pm 0.005$ & $33.60 \pm 1.25$ \\
Tetraselmis tetrathele & $0.021 \pm 0.005$ & $5.22 \pm 0.004$ & $28.48 \pm 1.05$ \\
\hline
\end{tabular}

Data represent mean \pm Standard Error (SE) of three replicates. 
Table 4

\begin{tabular}{lll}
\hline Parameters & Laboratory & Open raceway pond \\
\hline Lipid (\%) & $15 \pm 0.87$ & $19 \pm 0.98$ \\
Carbohydrate (\%) & $17 \pm 1.64$ & $21 \pm 1.69$ \\
Protein (\%) & $19 \pm 0.92$ & $28 \pm 0.87$ \\
\hline
\end{tabular}

Table 5

\begin{tabular}{lllll}
\hline $\begin{array}{l}\text { Culture } \\
\text { condition }\end{array}$ & Daily productivity & $\begin{array}{l}\text { Specific growth } \\
\text { rate } K\left(\text { div }^{-1}\right)\end{array}$ & Div./day & Gen. time (d) \\
& $\left(\mathrm{g} \mathrm{L}^{-1} \mathrm{~d}^{-1}\right)$ & &
\end{tabular}

\begin{tabular}{lllll}
\hline Open raceway & 0.063 & 0.45 & 0.64 & 1.55 \\
Laboratory & 0.050 & 0.39 & 0.56 & 1.79 \\
\hline
\end{tabular}

Data represent mean \pm Standard Error (SE) of three replicates 
Table 6

\section{Fatty acids}

Wt. \% (\%)

7-Octadecene

1.49

Methyltetradecanoate

2.63

Pentadecanoic acid, methyl ester

3.14

Palmitoleic acid, methyl ester

5.94

Palmitic acid, methyl ester

33.14

Hexadecanoic acid, 14-methyl-, methyl

ester

11-Octadecenoic acid, methyl ester

Heptadecanoic acid, 16-methyl-, methyl

21.94

ester

Cyclopropane octanoic acid 2-hexyl-

1.64 methyl ester

Data represent mean \pm Standard Error (SE) of three replicates 
a

b
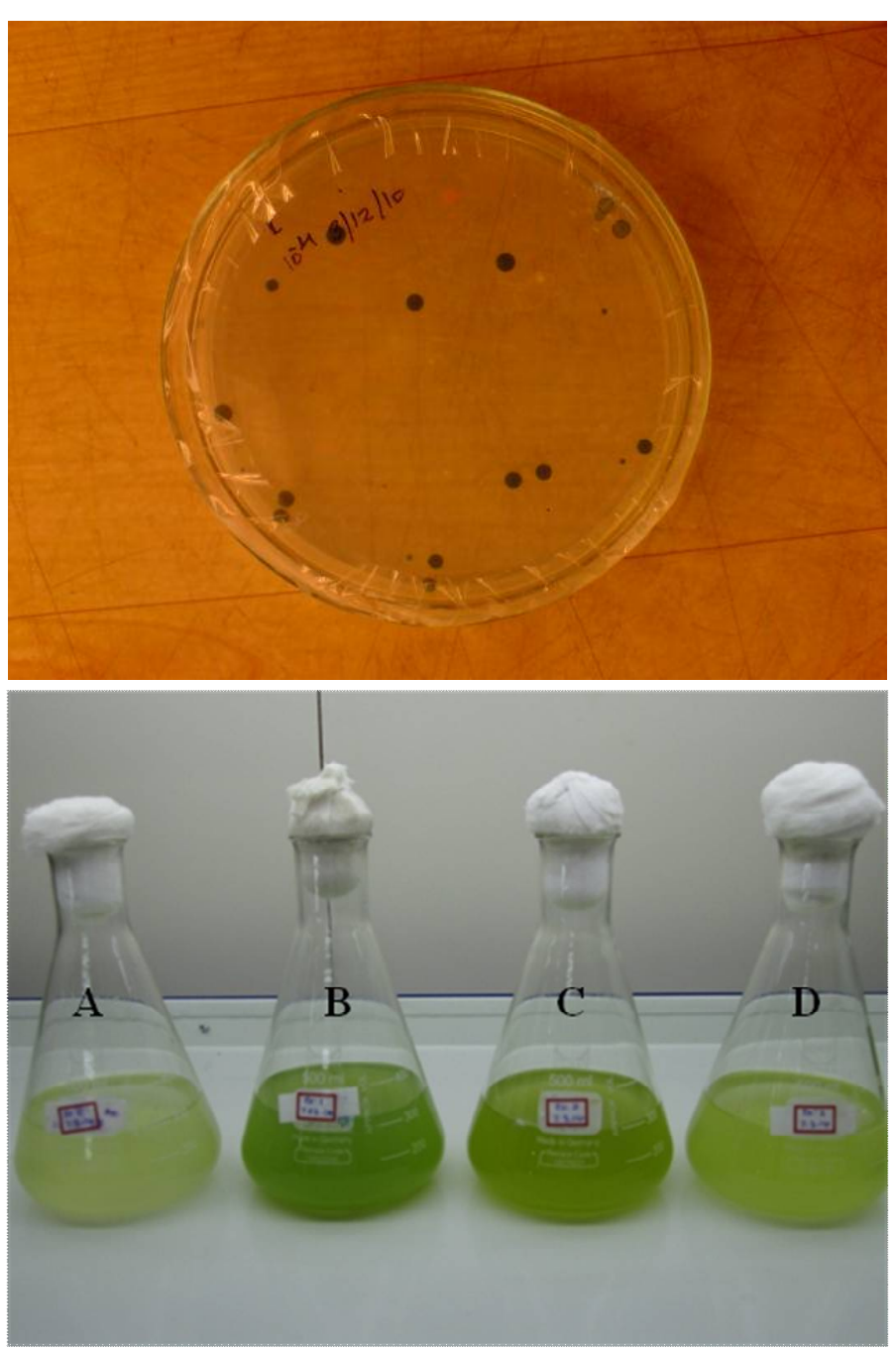

Fig. 1 
a

b
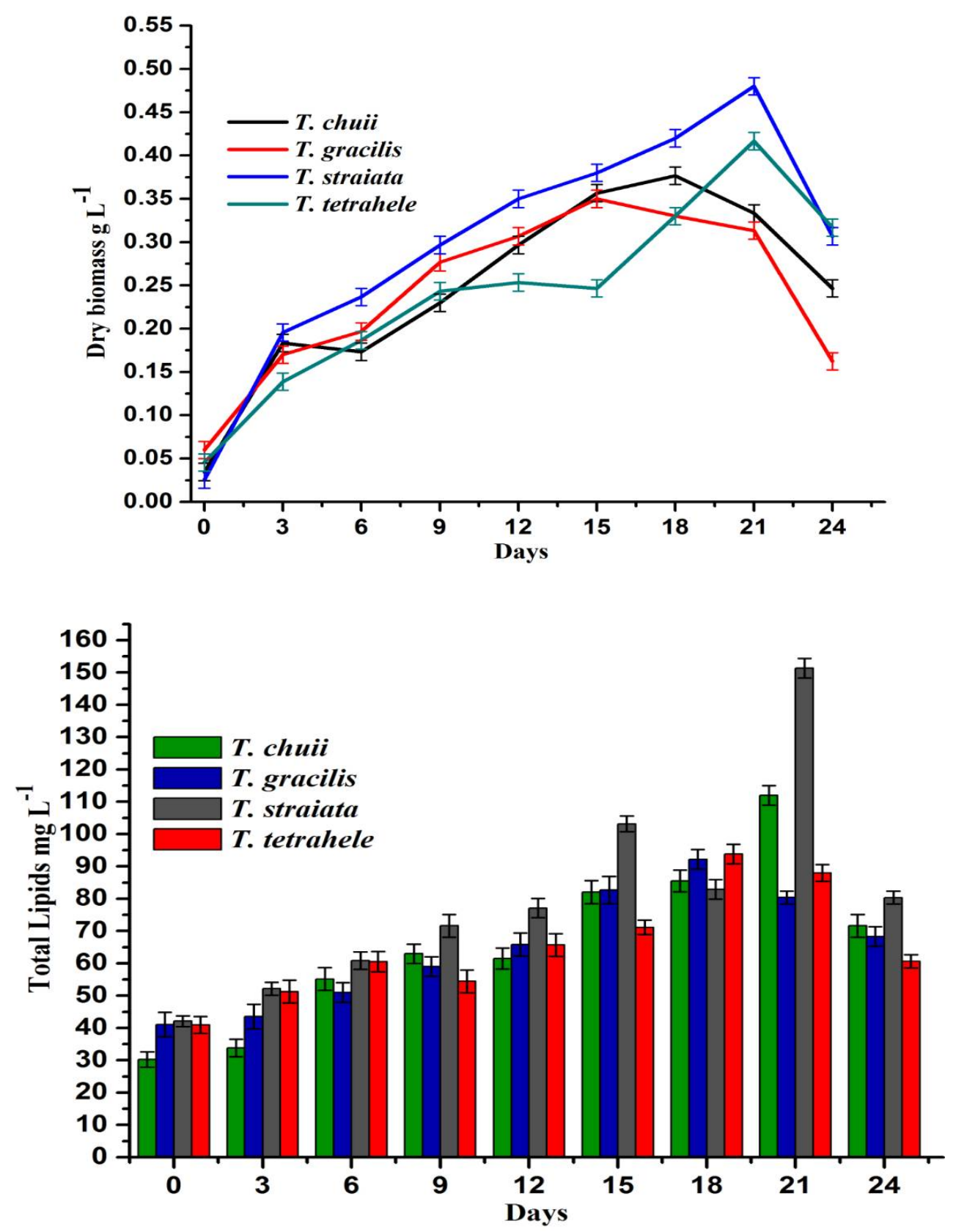

Fig. 2 


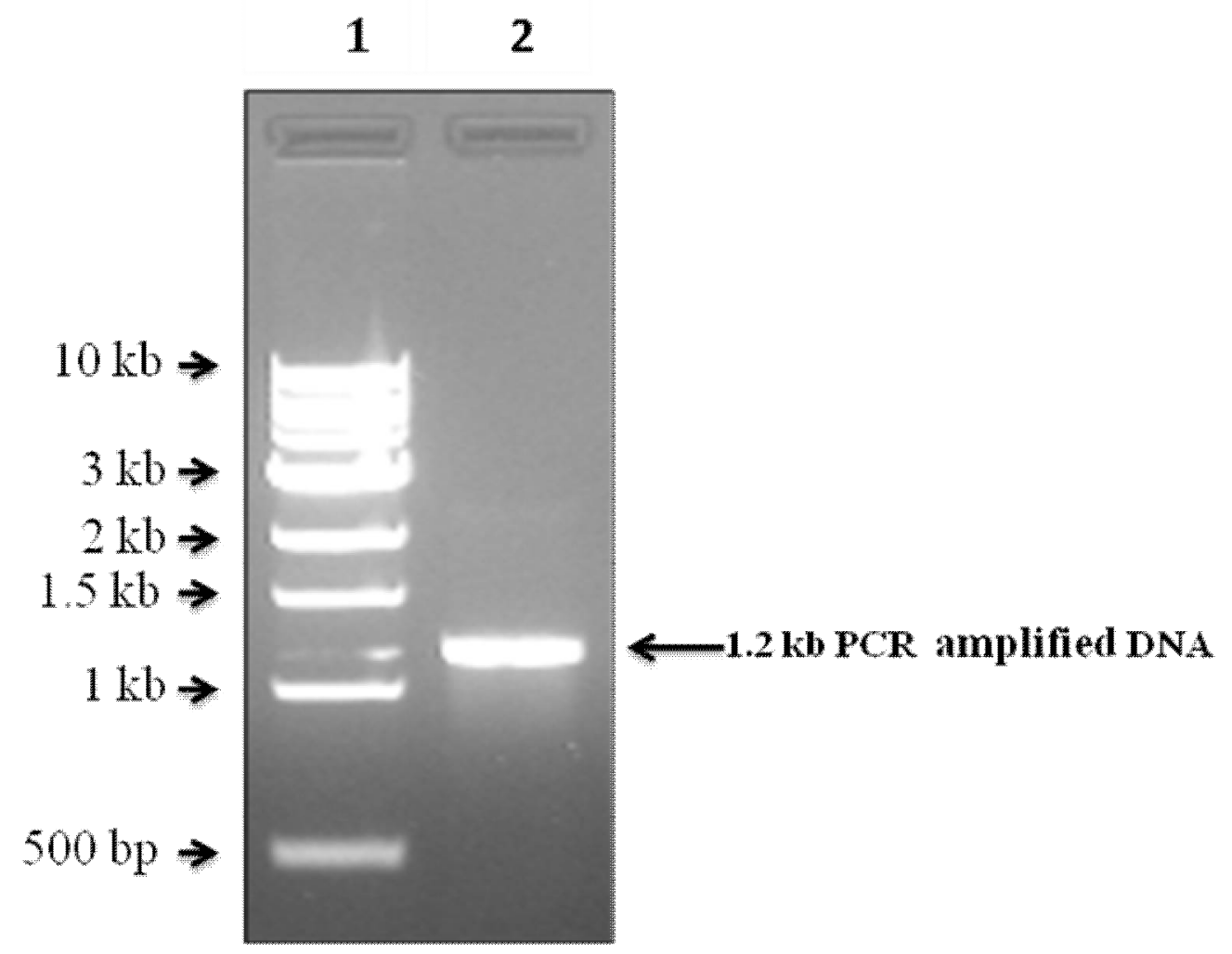

Fig. $3^{28}$ 
a

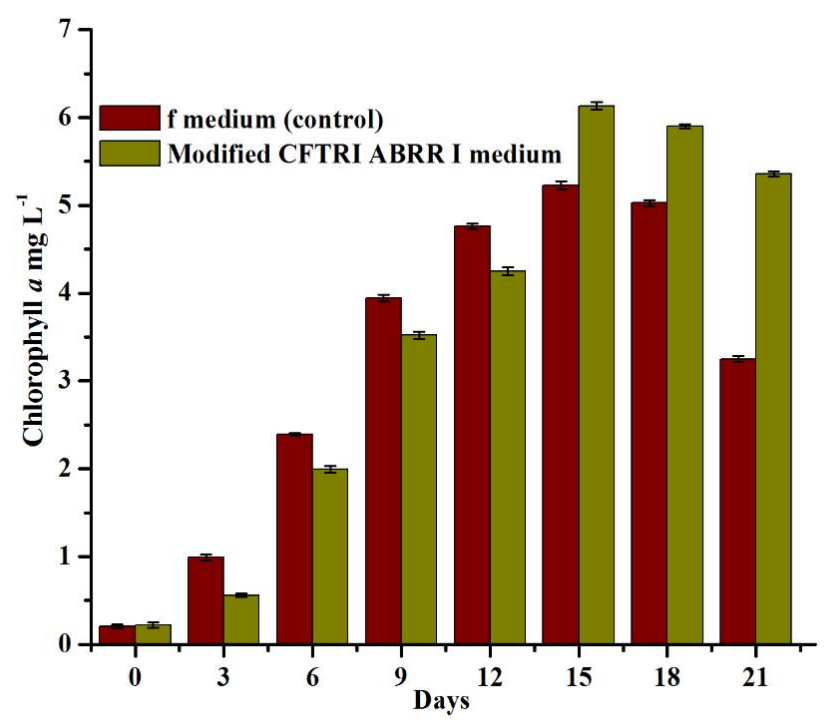

b

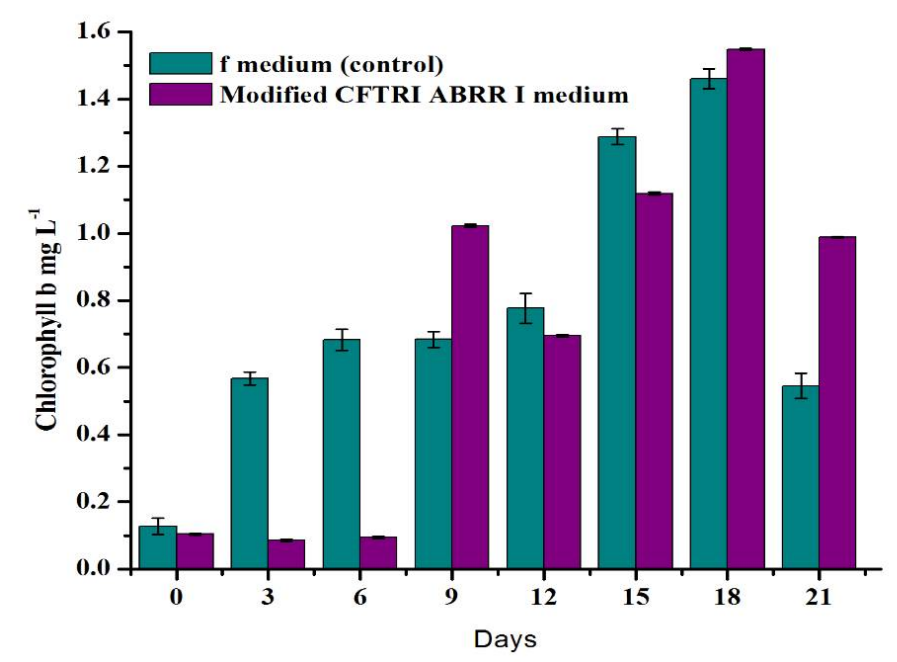

c

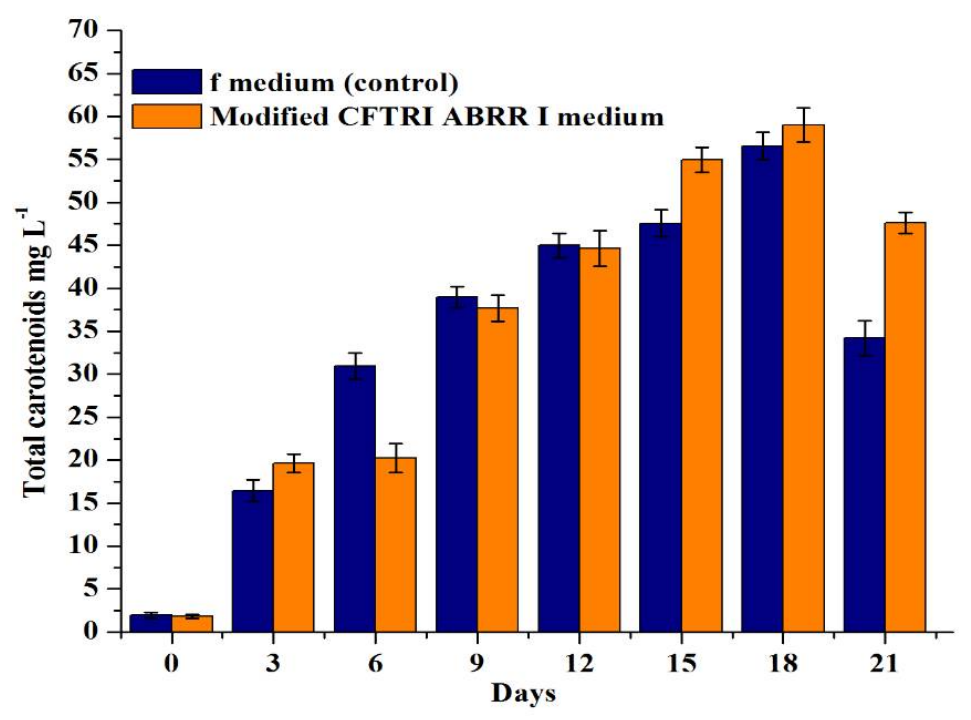

Fig. 4 


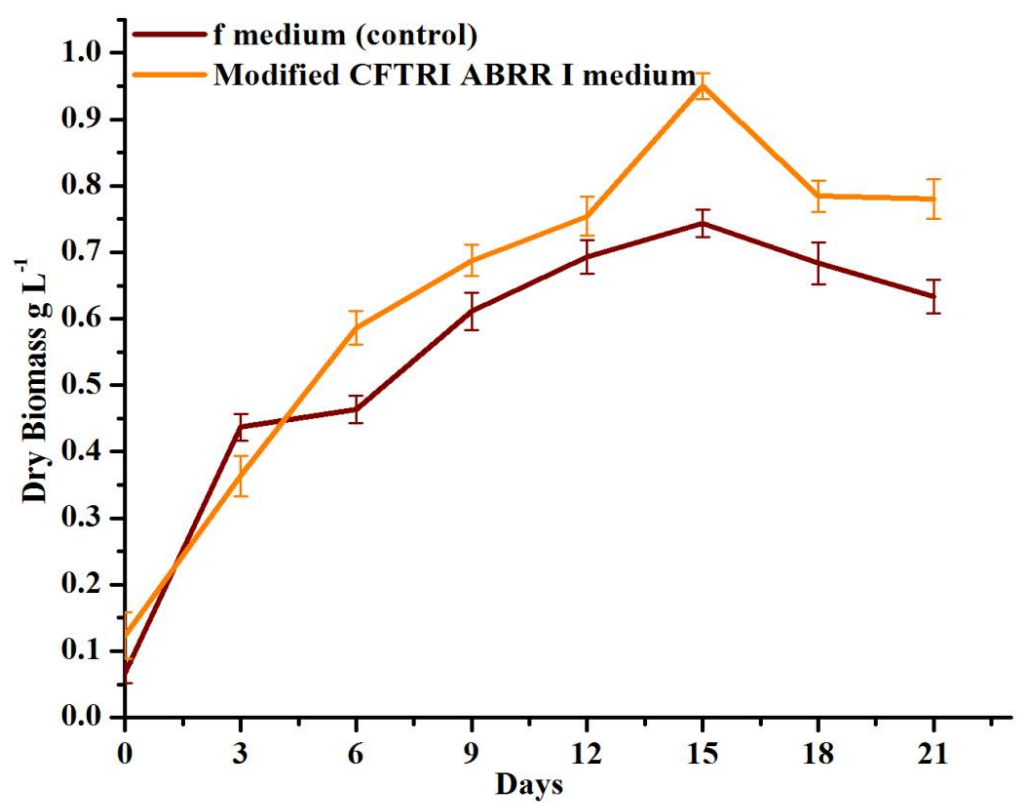

Fig. 5 